\title{
ISOLATION OF ANTIBACTERIAL PROTEIN/PEPTIDE FROM FICUS GLOMERATA LEAF
}

\author{
MANISHA THAPLIYAL, ANJALI BISHT, AJEET SINGH* \\ Department of Biotechnology, G. B Pant Engineering College, Pauri Garhwal \\ Email: ajeetsoniyal@gmail.com
}

Received: 21 Jul 2016, Revised and Accepted: 20 Aug 2016

\begin{abstract}
Objective: To isolate the antibacterial proteins/peptides from Ficus glomerata leaf.

Methods: Present study was designed to investigate antibacterial activity of proteins/peptides isolated from Ficus glomerata leaf. The isolated proteins/peptides were further checked for antibacterial activity against, Pseudomonas aeruginosa, Bacillus subtilis, Escherichia coli and Salmonella entrica bacterial pathogens.
\end{abstract}

Results: The results indicates that a $35 \mathrm{kDa}$ of protein were identified and exhibit good antibacterial activity against bacterial pathogen among all strains, Salmonella entrica and Pseudomonas aeruginosa exhibit good results with a clear zone of inhibition.

Conclusion: Ficus glomerata is popular for its medicinal properties against therapeutic potential. In the present study a novel protein with broad spectrum antibacterial activity. Microbes cause severe damage to plants which results in a large economic loss so; this protein can be use as an active agent in agriculture for plant protection and also in the development of novel therapeutic agents.

Keywords: Ficus glomerata, SDS-PAGE, Antimicrobial protein (AMPs), Antibacterial protein/peptide

(C) 2016 The Authors. Published by Innovare Academic Sciences Pvt Ltd. This is an open access article under the CC BY license (http://creativecommons.org/licenses/by/4.0/)

DOI: http://dx.doi.org/10.22159/ijcpr.2016v8i4.15271

\section{INTRODUCTION}

Since a long time period, medicinal plants have been a valuable source for the treatment of several disorders and possible source of antimicrobial agents. Application of medicinal plants and their products for the treatment of various human afflictions had been made by man since ancient time [1].

Ficus glomerata is a widely popular medicinal plant in India and its extracts have also been reported to possess significant various medicinal and pharmacological properties like anti-cancer, antimicrobial, and antioxidant activity [2]. Antibacterial properties of protein/peptide from Ficus glomerata were not reported till now and because of its high antibacterial activity, we took this plant for isolation of antibacterial protein/peptide. This plant can be used to determine bioactive natural products in the form of antimicrobial proteins/peptides, and that may serve for the development of new pharmaceuticals [3]. Protein and peptide were used in different disease states like cancer, diabetes, immuno-modulating, neurodegenerative effects as drug targeting to the specific site [4].

Most of the natural antimicrobial peptides are a range in size from 2 to $50 \mathrm{kDa}$ and have 10 to 50 amino acids in length and are positively charged, shows the helical structure and often contain a high position of hydrophobic amino acid [5]. Antimicrobial peptides are a group of numerous endogenous antibiotics and innate immune components that protect hosts against microbial infection and are produced predominantly in the natural environment. Hundreds of AMPs have been isolated from plants, insects, bacteria, fungi, mammals and so on [6] Despite the fact that plants do not have an immune system, they have developed a variety of potent defensive mechanisms, along with the synthesis of, proteins, low-molecularweight compounds and peptides with antifungal activity gradually.

This type of arrangement results in peptide attachment and insertion into the bacterial membrane to form trans membrane pores leading to membrane permeabilization. The amphipathic nature of antimicrobial peptides is needed for this method, as hydrophilic ion groups, it interacts with phospholipid groups additionally found within the membrane, while hydrophobic motifs directly interact with lipid elements of the membrane. The antifungal activity of AMP was initially ascribed to either fungal cell lysis or interference with fungal cell wall synthesis. Plant antifungal proteins comprise enzymes such as chitinases $[7,8]$ and $\beta-1$ 3 -glucanases [9] which can collaborate with membrane elements such as lipid transfer proteins (LTPs) [10], glycine/histidine-rich proteins, defensins [11-13] cyclophilin-like proteins and thaumatin-related protein [14-16]. The first antibacterial peptide was isolated from wheat flour, which has the potential to inhibit the growth of some phytopathogens such as, Corynebacterium michiganense, Xanthomonas campestris, and Pseudomonas solanacearum [17]. According to amino acid sequence homology, the main families of AMPs are thionins, defensins, cyclotides, snakins, have in like proteins and lipid transfer proteins, AMPs have been demonstrated to cease prokaryotic cells by targeting a variety of essential or metabolic processes at extracellular, intracellular sites and plasma membrane [18]. In silico study revealed some similarities in tertiary structures of antimicrobial plant proteins, although significant differences in amino acid sequences between the families.

Key features of AMPs are a high content of cysteine and glycine and the presence of disulfide bonds, which are important for intensifying structural stability under stress conditions. Small peptides are usually made in a cell either as precursor proteins or non-precursor proteins. The precursor protein can possess functional significance or be nonfunctional. The term nonfunctional is referring for those having no recognized, biological activity. The non-precursor-derived peptides encoded by SORFs are located in or near five regions of a gene [19]. Some antimicrobial peptides (AMPs) are made as precursor proteins that need to be processed to produce a functional peptide.

\section{MATERIALS AND METHODS}

\section{Bacterial strain}

Bacterial strains P. aeruginosa (424), B. subtilis (441), S. entrica (733) and E. coli (739) were collected from Microbial Type Culture Collection (MTCC), Institute of Microbial Technology (IMTECH), Chandigarh, India.

\section{Medicinal plants}

The Ficus glomerata leaves were collected from Haridwar, Uttarakhand.

\section{Sample preparation}

Plant leaves were first clean with tap water in order to remove all dirt and debris, later with distilled water. They were dried with tissue paper, cut in small pieces and were grinded in mortar pestle to make a fine powder. 


\section{Extraction of antibacterial protein/peptide}

Fresh 5 gm of leaves were grinded using extraction buffer $50 \mathrm{mmol}$ Tris$\mathrm{HCl}(\mathrm{pH} \mathrm{7.5)}$ and $0.5 \mathrm{M} \mathrm{NaCl}$ [20], after complete homogenization of leaves, kept the sample for $12 \mathrm{hr}$ incubation period. After that, spin at $12,000 \mathrm{rpm}$ for $20 \mathrm{~min}$ in a cooling centrifuge. After centrifugation, the resulting supernatant was investigated for further studies.

\section{Evaluation of total protein concentration by bradford assay}

Total protein content of the Ficus glomerata leaf extract was estimated spectrophotometrically by Bradford method using BSA stock solution $(2 \mathrm{mg} / \mathrm{ml})$ at $595 \mathrm{~nm}[21]$.

\section{Antibacterial activity assay}

Antibacterial test of protein from Ficus glomerata leaves was done against pathogens P. aeruginosa (424), B. subtilis (441), S. entrica (733) and E. coli (739) by Agar well diffusion method [22]. The strain of each bacterium was swabbed equally onto the Petri plates having Nutrient agar media. Wells were made by the help of borer. The sample was loaded onto each wells of different concentration using sterile micropipette. Incubate at $32{ }^{\circ} \mathrm{C}$ for $24 \mathrm{~h}$. Then zone of inhibition was measured.

\section{SDS-page}

Sodium dodecyl sulphate-polyacrylamide was carried out according to the Laemmli method [23]. The sample for analysis was dissolved in sample buffer $(0.125 \mathrm{M}$ Tris pH 6.8, 2.5\% SDS, 20\%glycerol, $0.002 \%$ bromophenol blue, $10 \% \beta$-mercapto-ethanol) boiled for 5 minutes. The supernatant $(35 \mu \mathrm{g})$ of protein sample was loaded onto the gel. Gel consisting of $10 \%$ resolving gel and $10 \%$ stacking gel using electrophoresis unit (Bio-Rad) to get the separated peptides of different molecular weight. Electrophoresis was performed with $100 \mathrm{~V}$ until reached the bottom of the resolving gel. After this, gel was stained with Comassive Brilliant Blue R-250 and destain with $40 \%$ methanol and $10 \%$ glacial acetic acid solution. Different bands resulted after destaining. The molecular mass of antibacterial protein/peptide was determined by the molecular marker.

\section{RESULTS}

The present study was focused on the isolation of antibacterial activity conferring protein from the Ficus glomerata leaves. They are identified as important components of the innate defense system of bacteria, fungi, insects, animals and plants. Leaves sample were used for further analysis.

\section{Antimicrobial activity of protein extract}

The antibacterial activity of the crude protein extract from leaves was determined by Agar well diffusion assay. Antibacterial activity of plant extract with extraction buffer was tested against different bacterial strains. Among all strains, Salmonella entrica and Pseudomonas aeruginosa exhibit good results with a zone of inhibition $18 \pm 1.24$ and $19.6 \pm 1.44$.

Table 1: Zone of inhibition ( $\mathrm{mm}$ ) of protein extract against bacterial pathogen

\begin{tabular}{|c|c|c|c|}
\hline Pathogens & Negative control & Tetracycline (Positive control) & $200 \mu \mathrm{l}$ \\
\hline Pseudomonas aeruginosa & 0 & 13 & $19.6 \pm 1.44$ \\
\hline Escherichia coli & 0 & 13 & $18.3 \pm 1.65$ \\
\hline Salmonella enterica & 0 & 13 & $18 \pm 1.24$ \\
\hline Bacillus subtilis & 0 & 13 & $17.3 \pm 1.90$ \\
\hline
\end{tabular}

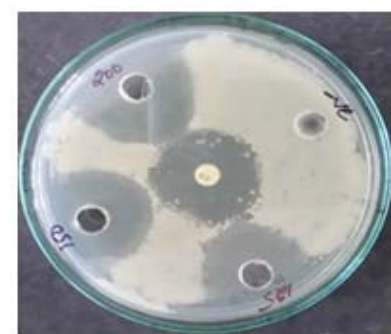

A

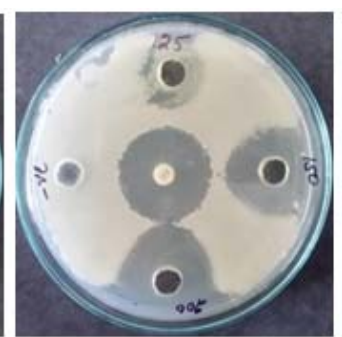

B

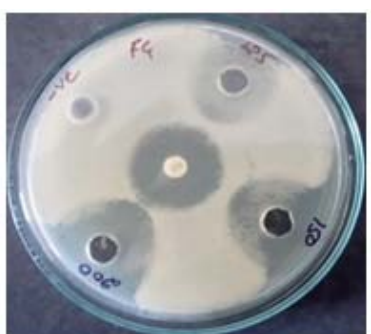

C

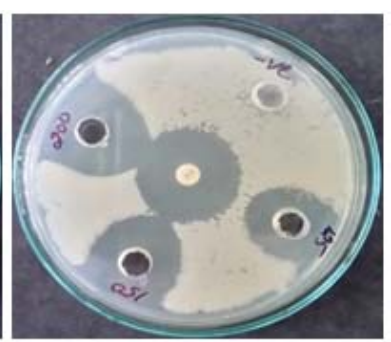

D

Fig. 1: Antibacterial activity of crude protein against different bacterial pathogens, 'A' shows antibacterial activity against Pseudomonas aeruginosa, 'B' shows against Bacillus subtilis, 'C' shows against Escherichia coli and 'D' shows against Salmonella enteric

\section{Sodium dodecyl sulphate-polyacrylamide gel electrophoresis}

Proteins were run on an SDS-PAGE. The migration of molecular mass standards is indicated in $\mathrm{kDa}$ on the left-hand side. On the basis of Bradford results, the total amount of protein were determined, and $33 \mu \mathrm{g}$ of protein was loaded on wells. The molecular profiling of sample was observed and indicates the presence of a protein with a molecular weight ranging from $8 \mathrm{kDa}$ to $245 \mathrm{kDa}$ and according to the previously reported studies the protein bands distinguish in this study was used for the further activity.

\section{Antibacterial activity of eluted protein sample}

To check the antibacterial activity of protein band, it was first eluted by elution buffer, further test against different bacterial pathogens. As shown in fig. 3 ' $A$ ' shows a clear zone of inhibition of $12 \mathrm{~mm}$ at $150 \mu \mathrm{l}$ of protein content and $14 \mathrm{~mm}$ at $200 \mu \mathrm{l}$ of eluted protein content against bacterial pathogen Pseudomonas aeruginosa. Same as 'B' found to be very effective on Salmonella entrica. with a zone of inhibition $12 \mathrm{~mm}$ with $150 \mu \mathrm{l}$ of protein and $14 \mathrm{~mm}$ at $200 \mu \mathrm{l}$ of protein, the negative control is Tris- $\mathrm{Cl}(\mathrm{pH}=8)$.

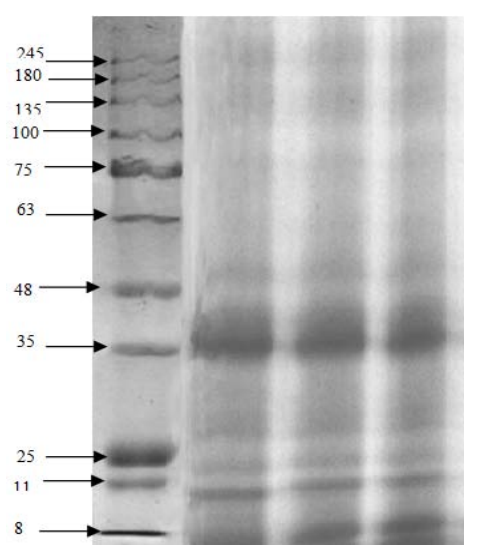

Fig. 2: SDS-PAGE analysis of protein extracted from Ficus glomerata leaf. $35 \mu \mathrm{g}$ of protein were loaded in each well, lane of molecular weight marker indicated at the left 


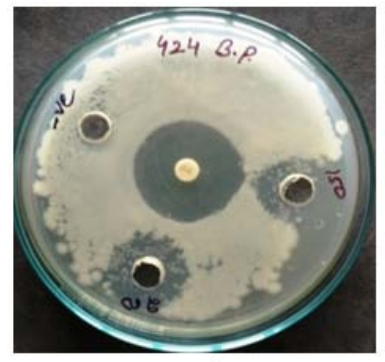

A

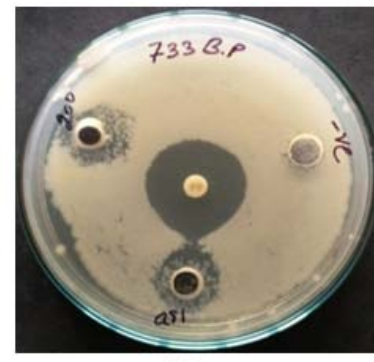

B
Fig. 3: This fig. shows antibacterial activity of small protein/peptide having molecular weight $35 \mathrm{kDa}$ against two pathogenic strain Pseudomonas aeruginosa and Salmonella entrica

\section{Statistical analysis}

All the experiments were carried out in triplicate thrice $(n=3)$. The statistical analysis of the data was carried out by analysis of the variance (ANOVA). Results were considered significant when $\mathrm{p}<0.05$.

\section{DISCUSSION}

This study described the isolation of antimicrobial protein from ficus glomerata leaf; we found that the isolated protein exerted strong antibacterial activity against gram positive and gram negative bacteria that is Bacillus subtilis and Pseudomonas aeruginosa with a high zone of inhibition to control diseases and enhance the growth of the early plant.

In the previous study, antimicrobial peptides with gram positive and gram negative bacteria growth inhibiting ability have been reported [24]. Numerous types of molecules with antibacterial activity have been isolated from plants $[25,26]$.

According to the World Health Organization (WHO), medicinal plants would be the capable source to obtain a variety of active compounds and drug. Therefore, such plants should be investigated to finer understand their properties, efficiency and safety [27]. Hence an attempt is made to explore the possible antimicrobial peptides generated through the medicinal plant. In previous studies, A $7.8 \mathrm{kDa}$ of antimicrobial protein was isolated from the Seeds of Motherwort [28]. Similar to our study we found $35 \mathrm{kDa}$ of protein isolated from Murraya Koenigii [29].

Several Amps have been reported, purified and characterized by using a large variety of techniques like, ion exchange chromatography, RP-HPLC those are quite expensive and timeconsuming [30, 31]. Here, we have isolated the antibacterial proteins/peptides from Ficus glomerata leaf by cost-effective and time-saving methods for plant protection and therapeutic potential.

\section{CONCLUSION}

It is concluded that the traditional plants may represent new sources of antimicrobials with the use of AMPs as single therapeutic antibiotic agents. In the current study, a novel antimicrobial protein was identified from Ficus glomerata leaf. The results showed that $35 \mathrm{kDa}$ of protein were identified and exhibit broad spectrum antibacterial activity against bacterial pathogen and can further use to develop novel therapeutic agents and biologically active component in agriculture as plant protection agents.

\section{ACKNOWLEDGEMENT}

The authors are thankful to Govind Ballabh Pant Engineering College, Pauri-Garhwal to provide lab facility and TEQIP II for a financial assistantship.

\section{CONFLICT OF INTERESTS}

Declare none

\section{REFERENCES}

1. Mahmood A, Raja GK, Mahmood T, Gulfraz M, Khanum A. Isolation and characterization of antimicrobial activity conferring component (s) from seeds of bitter gourd (Momordica charantia). J Med Plant Res 2012;6:566-73.

2. Sudhakar A. Phytochemical screening of Ficus glomerata. Roxb. Galled leaves. Int J Pharm Biomed Res 2012;3:105-7.

3. Kamala G, Vutukuru SS, Rani JU, Meghanath P, Pasha C. Screening of small peptides from various germinating seeds having antimicrobial activity. J Pharm Bioanal Sci 2016;11:2278-3008.

4. Keservani RK, Sharma AK, Jarouliya U. Protein and peptide in drug targeting and its therapeutic approach. Ars Pharm 2015;56:165-77.

5. Goyal RK, Mattoo AK. Plant antimicrobial peptides. In: Richard M Epand. editors. Host Defense Peptides and Their Potential as Therapeutic Agents. 1st ed. America: Springer International Publishing; 2011. p. 111-36.

6. Epand RM, Vogel HJ. The diversity of antimicrobial peptides and their mechanisms of action. Biochim Biophys Acta 1999;1462:11-28.

7. Roberts WK, Selitrennikoff CP. Isolation and partial characterization of two antifungal proteins from barley. Biochim Biophys Acta 1986;880:161-70.

8. Huynh QK, Hironaka CM, Levine EB, Smith CE, Borgmeyer JR, Shah DM. Antifungal proteins from plants. Purification, molecular cloning, and antifungal properties of chitinases from maize seeds. Am J Biochem 1992;267:6635-40.

9. Leah R, Tommerup H, Svendsen IB, Mundy J. Biochemical and molecular characterization of three barley seed proteins with antifungal properties. Am J Biochem 1991;266:1564-73.

10. Terras FR, Goderis IJ, Leuven FV, Vanderleyden I, Cammue BP, Broekaert WF. In vitro antifungal activity of a radish (Raphanus sativus $L$.) seed protein homologous to nonspecific lipid transfer proteins. Plant Physiol 1992a;100:1055-8.

11. Terras FRG, Schoofs HME, De Bolle MFG, Van-FL, Rees SB, Vanderleyden J, et al. Analysis of two novel classes of plant antifungal proteins from radish (Raphanus sativus L.) seeds. J Biol Chem 1992b;267:15301-9.

12. Terras FR, Torrekens S, Leuven FV, Osborn RW, Vanderleyden J, Cammue B, et al. A new family of basic cysteineich plant antifungal proteins from Brassicaceae species. FEBS Lett 1993;316:233-40.

13. Terras FR, Eggermont K, Kovaleva V, Raikhel NV, Osborn RW, Kester A, et al. Small cysteine-rich antifungal proteins from radish: their role in host defense. Plant Cell 1995;7:573-88.

14. Wang SY, Wu JH, Ng TB, Ye XY, Rao PF. A non-specific lipid transfer protein with antifungal and antibacterial activities from the mung bean. Peptides 2004;25:1235-42.

15. Wong JH, Ng TB. Sesquin, a potent defensin-like antimicrobial peptide from ground beans with inhibitory activities toward tumor cells and HIV-1 reverse transcriptase. Peptides 2005;26:1120-6.

16. Ferreira RB, Monteiro SARA, Freitas R, Santos CN, Chen Z, Batista LM, et al. The role of plant defense proteins in fungal pathogenesis. Mol Plant Pathol 2007;8:677-700.

17. De Caleya RF, Gonzalez-Pascual B, García-Olmedo F, Carbonero P. Susceptibility of phytopathogenic bacteria to wheat puro thionins in vitro. Appl Microbiol 1972;23:998-1000.

18. Yount NY, Yeaman MR. Peptide antimicrobials: cell wall as a bacterial target. Annal New York Acad Sci 2013;1277:127-38.

19. Tavormina P, Coninck BD, Nikonorova N, Smet DI, Cammue BP. The plant peptidome: an expanding repertoire of structural features and biological functions. Plant Cell 2015;27:2095-118.

20. Ranjan S, Matcha R, Madhuri B, Narendra Babu PVR. Comparative evaluation of protein extraction methods from few leguminous seeds. Int J Adv Biotechnol Res 2012;3:558-63.

21. Bradford MM. A rapid and sensitive method for the quantitation of microgram quantities of protein utilizing the principle of protein-dye binding. Anal Biochem 1976;72:248-54.

22. Ramadan ES. Synthesis, spectral characterization and antimicrobial activity of novel 2-hydrazono-2(3H)-thiazole derivatives derived from 4-(3-Chlorophenyl)-3thiosemicarbazide. Int J Pharm Pharm Sci 2016;8:176-82.

23. Laemmli UK. Cleavage of structural proteins during the assembly of the head of bacteriophage T4. Nature 1970;227:680-5.

24. Reddy KVR, Yedery RD, Aranha C. Antimicrobial peptides: premises and promises. Int J Antimicrob Agents 2004;24:536-47. 
25. Boonnak N, Karalai C, Chantrapromma S, Ponglimanont C, Fun $\mathrm{HK}$, Kanjana-Opas A, et al. Anti-Pseudomonaaeruginosa xanthones from the resin and green fruits of Cratoxylum cochinchinense. Tetrahedron 2009;65:3003-13.

26. Mahabusarakam W, Rattanaburi S, Phongpaichit S, KanjanaOpas A. antibacterial and cytotoxic xanthones from Cratoxylum cochinchinense. Phytochem Lett 2008;1:211-4.

27. Mothana RAA, Gruenert R, Bernarski PJ, Lindequist U. Evaluation of the in vitro anticancer, antimicrobial and antioxidant activities of some Yemeni plants used in folk medicine. Pharmazie 2009;64:260-8.

28. Yang X, Xiao Y, Wang X, Pei Y. Expression of a novel small antimicrobial protein from the seeds of motherwort (Leonurus japonicus) confers disease resistance in tobacco. Appl Environ Microbiol 2007;73.3:939-46.
29. Ningappa MB, Dhananjaya BL, Dinesha R, Harsha R, Srinivas L. Potent antibacterial property of APC protein from curry leaves (Murraya koenigii L.). Food Chem 2010;118:747-50.

30. Dahot MU. Antibacterial and antifungal activity of small protein of Indigofera oblongifolia leave. J Ethnopharma 1999; 64:277-82.

31. Mateen A, Tanveer Z, Janardhan K, Gupta VC. Screening and purification of antimicrobial proteins/peptides from some of the medicinal plant's seeds. Int J Pharm Biol Sci 2015;6:774-8.

\section{How to cite this article}

- Manisha Thapliyal, Anjali Bisht, Ajeet Singh. Isolation of antibacterial protein/peptide from Ficus glomerata leaf. Int J Curr Pharm Res 2016;8(4):24-27. 